\title{
The influence of the welding environment on the properties of Tekken joints made from S355J2C $+\mathrm{N}$ steel
}

\section{Keywords:}

underwater welding;

covered electrodes;

cold cracking;

hardness measurements; weldability

\begin{abstract}
There are three main methods of underwater welding: dry, wet and intermediate between them, by using the local dry chamber. Due to low costs, the most common method is the wet welding with the use of covered electrodes. Water as a welding environment carries out a lot of problems. The first is limited visibility and instability of the welding arc. The biggest problem during underwater welding is high susceptibility to cold cracking, resulting from the increased diffusible hydrogen content in deposited metal and high stress values.

In the work, Tekken joints from S355J2C+N steel were made in air and in water environment. The joints were subjected to non-destructive visual (VT) and penetrant (PT) tests. Then, macroscopic tests and hardness measurements were performed. The results confirm the literature reports that the water environment causes an increase in hardness in the heat affected zone (HAZ), which promotes the formation of cracks in welding joints.
\end{abstract}

\section{Introduction}

There are three basic methods of welding in the water environment $[1 \div 4]$ :

- wet welding - due to the low costs most often used, it does not require specialized equipment, during the process the area of the formed joint and the electric arc are in contact with the water environment;

- dry welding - the most expensive method of underwater welding, which results from the need to build special chambers that isolate the welder, joint area and electric arc from the environment, the method occurs in two varieties - isobaric (pressure equal to air pressure) and hyperbaric (pressure resulting from welding depth);

- welding with the local dry chamber - is an indirect method, isolated from the water is only the welding area with the electric arc, while the welder is in the water, the method allows to obtain better joints than in the case of dry welding, however, due to the arc not being visible to the welder does not find as wide application as the two above.

The diagram of underwater welding methods is presented in Figure 1.

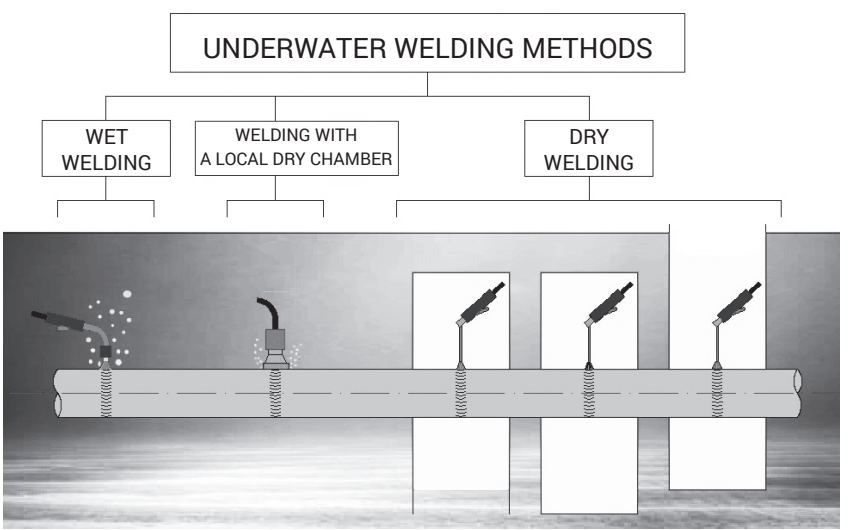

Fig. 1. Schematic diagram of underwater welding methods

The most common method of wet welding is welding with covered electrodes. In addition to economic reasons, its broad application also results from the fact that it provides the welder with a relatively large freedom of movement [5:7]. Unfortunately, this method carries a lot of problems that significantly worsen the quality of joints made in an aquatic environment. From the point of view of the implementation

dr inż. Jacek Tomków, inż. Anna Janeczek - Gdańsk University of Technology

Corresponding author: jacek.tomkow@pg.edu.pl 


\begin{tabular}{|c|c|c|c|c|c|c|c|c|c|c|c|}
\hline \multicolumn{12}{|c|}{ Element content, \% wt } \\
\hline & C & Si & Mn & $\mathbf{P}$ & $\mathrm{Cr}$ & Mo & $\mathrm{Ni}$ & s & $\mathrm{Cu}$ & v & $\mathrm{Ce}_{\text {MIS }}$ \\
\hline $\begin{array}{l}\text { according } \\
\text { to the control analysis }\end{array}$ & 0.196 & 0.501 & 1.1 & 0.017 & 0.02 & 0.001 & 0.001 & 0.006 & 0.016 & 0.005 & 0.386 \\
\hline$C e_{M I S}=C+\frac{C r+M o+V}{5}+$ & & & & & & & & & & & \\
\hline
\end{tabular}

of the process, the biggest problem is the instability of the electric arc's burning. This in turn directly affects the quality of welds, which can be characterized by porosity, shape

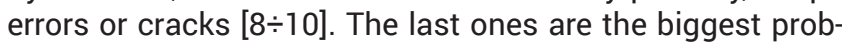
lem encountered during welding in the aquatic environment. There are several reasons for the forming of cold cracks, and among the most important ones that are encountered in the aquatic environment are $[11 \div 15]$ :

- increased cooling rate of joint, translating into high stress value;

- high content of diffusible hydrogen in deposited metal;

- brittle microstructure in HAZ.

The water environment significantly hampers the prevention of cold cracks. In the case of welding in the air, many effective methods are known, such as pre-heating or drying the electrodes. When running a process under water, a significant number of them is impossible or difficult to implement due to prevailing conditions. Currently, a global research trend is observed, the aim of which is to develop effective methods that can be applied during underwater welding. Promising results were obtained for induction heating of welded sheets, which, however, causes large problems with arc stability [16]. Additional methods are ultrasonic support $[17,18]$, reduction of the amount of gas bubbles emitted, which affects the amount of diffusible hydrogen [19] and welding with the use of tempering beads $[8,20]$

The aim of the research was to assess the impact of the welding environment on the properties of Tekken test joints made of $5355 \mathrm{~J} 2 \mathrm{C}+\mathrm{N}$ steel with the use of covered electrodes. Two Tekken test joints were made in accordance with the guidelines of PN-EN ISO 17642-2:2005. One sample was welded in the air and the other in an water environment. The samples were subjected to non-destructive visual (VT) and penetration (PT) tests. Then, macroscopic tests and hardness measurements using the Vickers HV10 method were performed.

\section{Own research}

The tests were carried out using construction steel sheets with a thickness of $16 \mathrm{~mm}$, normalized with S355J2C+N (according to PN-EN 10025-2:2007). The chemical composition of the steel has been analyzed using the emission spectrometry method with spark excitation, the results of which are presented in the Table I. Table II shows selected mechanical properties of the tested steel.

Welding was done in tap water at a temperature of about $20^{\circ} \mathrm{C}$ and a depth of $105 \mathrm{~mm}$, the diagram of which is presented in Figure 2.

Table II. Mechanical properties of S355J2C+N steel, acc. to PN-EN 10025-2:2007

\begin{tabular}{|c|c|c|}
\hline $\begin{array}{c}\text { Yield Stress } \\
\text { YS [MPa] }\end{array}$ & $\begin{array}{c}\text { Ultimate Tensile } \\
\text { Strength UTS [MPa] }\end{array}$ & $\begin{array}{c}\text { Minimal elongation } \\
\mathbf{A}_{5}[\%]\end{array}$ \\
\hline 355 & 470 & 17 \\
\hline
\end{tabular}

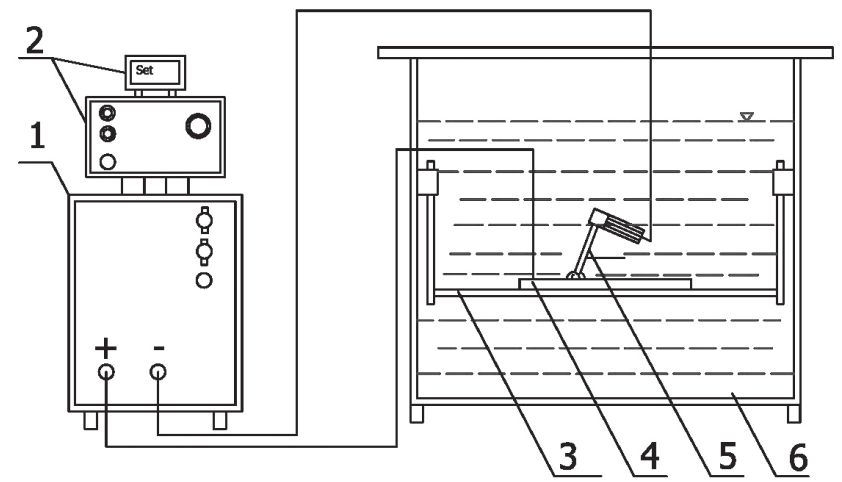

Fig. 2. The schema of the underwater welding at shallow depths: 1 - welding power source, 2 - control panel wire feeder, 3 - table, 4 - plate, 5 - electrode, 6 - tank

The Omnia (E $380 \mathrm{R} 11$ ) rutile covered electrodes from Lincoln Electric with a diameter of $4.0 \mathrm{~mm}$ were used for welding. These electrodes were chosen due to the universality of use, not only depending on the environment, but also the welding position and good plastic properties of the weld metal and the ease of ignition of the welding arc. Their chemical composition and mechanical properties are shown in Table III.

During the research, two Tekken samples were made, one on air and one in an water environment. Both were DC- welded, as recommended by the electrode manufacturer. The Tekken sample scheme is shown in Figure 3. Process parameters are presented in Table IV.

During welding, a significant difference in the process was observed. In the case of welding in the air, no problems were encountered related to the stability of the electric arc's burning. The transfer of the process to the water environment caused that the arc required higher voltages, and the process itself was unstable.

Table III. Chemical composition (wt.\%) and mechanical properties of Omnia rutile electrodes [21]

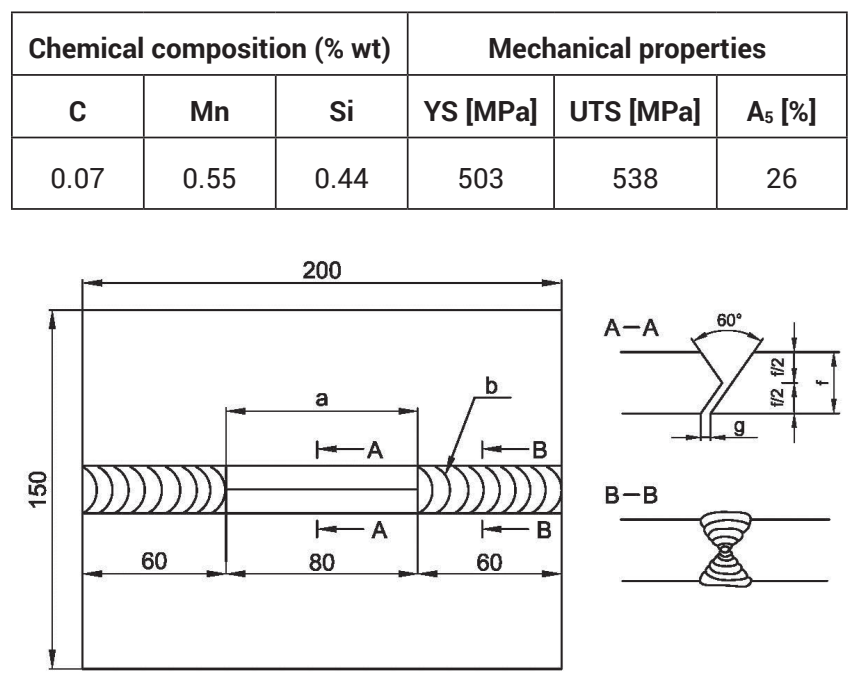

Fig. 3. Schematic illustration of the Tekken test specimen acc. to PN-EN ISO 17642-2 
Table IV. Welding conditions of Tekken test joints

\begin{tabular}{|c|c|c|c|c|}
\hline $\begin{array}{c}\text { No. of the } \\
\text { sample }\end{array}$ & $\begin{array}{c}\text { I } \\
{[\mathrm{A}]}\end{array}$ & $\begin{array}{c}\mathrm{U} \\
{[\mathrm{V}]}\end{array}$ & $\begin{array}{c}\mathrm{Vsp} \\
{[\mathrm{mm} / \mathrm{s}]}\end{array}$ & $\begin{array}{c}\text { ql } \\
{[\mathrm{kJ} / \mathrm{mm}]}\end{array}$ \\
\hline \multicolumn{6}{|c|}{ Sample made under the water } \\
\hline W1 & 184 & 27 & 6,87 & 0,72 \\
\hline \multicolumn{5}{|c|}{ Sample made in the air } \\
\hline P2 & 162 & 23,6 & 3,47 & 1,10 \\
\hline
\end{tabular}

\section{Non-destructive testing}

The next step after making the samples were non-destructive tests. They were carried out in accordance with the recommendations of PN-EN ISO 17637:2017-02 (VT) and PN-EN ISO 3452-1:2013-08 (PT). Figures 4 and 5 present the results of non-destructive testing for both samples.

\section{Metallographic examinations}

Metallographic examinations were carried out in accordance with the guidelines of PN-EN ISO 17639:2013-12. Two microsections were evaluated in each sample for the occurrence of cracks in the heat affected zone and on the fusion line. Samples prepared in this way were etched with $4 \%$ of nital. A significant difference was observed for samples made in different environments. The joint made in the air did not have any imperfections. In the case of a joint made underwater, a cold crack was identified in the HAZ near the fusion line or through the fusion line that separated the joint into two fragments. The exemplary results of macroscopic examinations are presented in Figures 6 and 7.

\section{Hardness measurements}

The next step was to measure the hardness using the Vickers HV10 method in accordance with the requirements of PN-EN ISO 9015-1:2011. A hardness measurement device manufactured by the Sinowon Company (model HV$50 \mathrm{M})$ was used to carry out the tests. Schematic layout of hardness measurement points' distribution is presented in Figure 8. 380 HV10 in accordance with PN-EN ISO 15614-1:2008 was accepted as the hardness limit for steel S355J2C+N.

It was observed that the transfer of the welding process to the water environment influences a significant increase in the hardness of both the heat affected zone and the weld metal itself. In the case of a joint made in the air, in no case was the exceeding of the accepted hardness limit noted. However, when measuring the hardness of a sample welded under the water, exceeding the $380 \mathrm{HV} 10$ criterion was noted for every measurement. The results of hardness measurements are presented in Table V. Examples of distributions for individual points can be found in Figure 9. a)

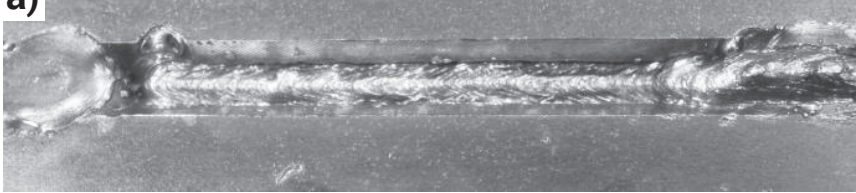

b)

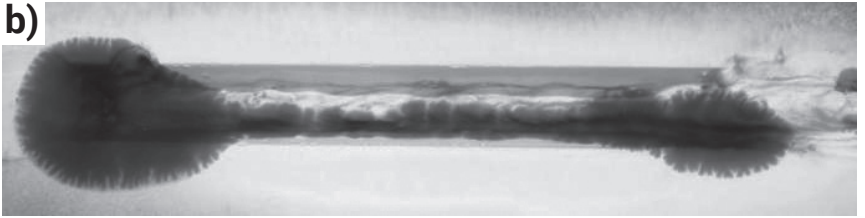

Fig. 4. Results of non-destructive testing for specimen W1, welded in the water, a) VT - wrong shape, b) PT - indication through the all length of the weld
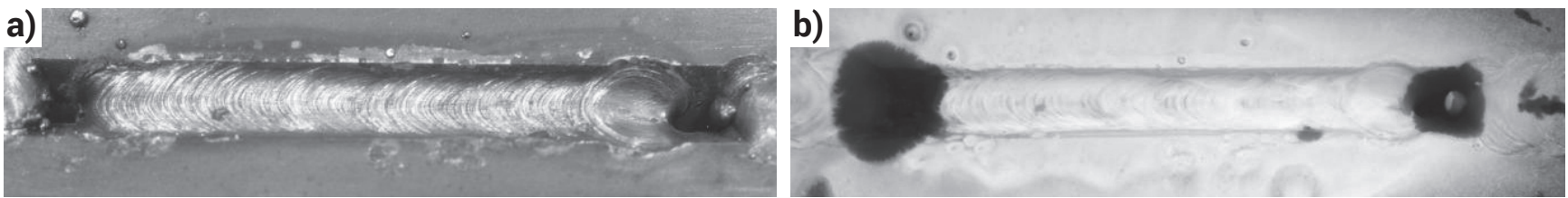

Fig. 5. Results of non-destructive testing for specimen P2, welded in the air, a) VT - crack in the crater, b) PT - crack in the crater
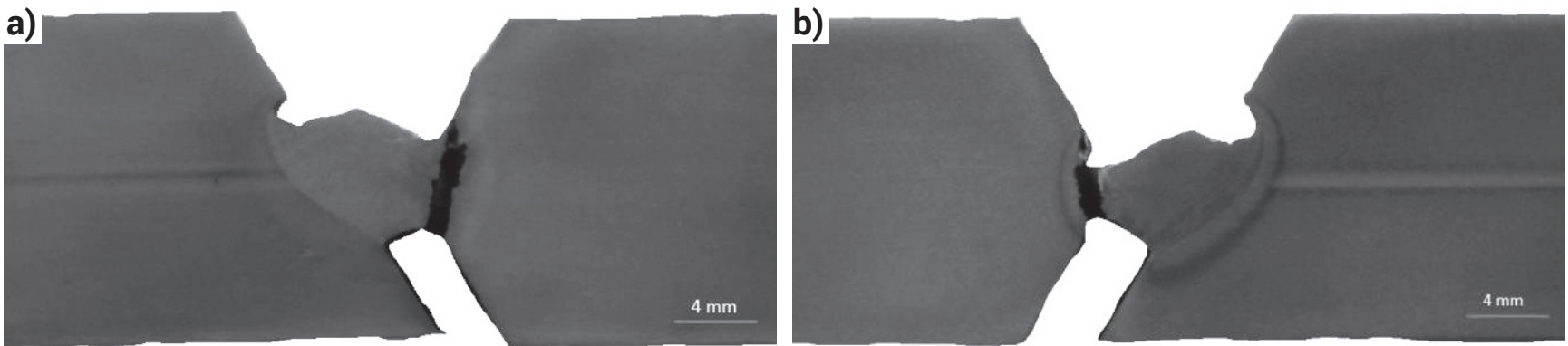

Fig. 6. Results of macroscopic testing for specimen welded in the water; a) Specimen W1.1, b) Specimen W1.2 - crack run through the fusion line and $\mathrm{HAZ}$
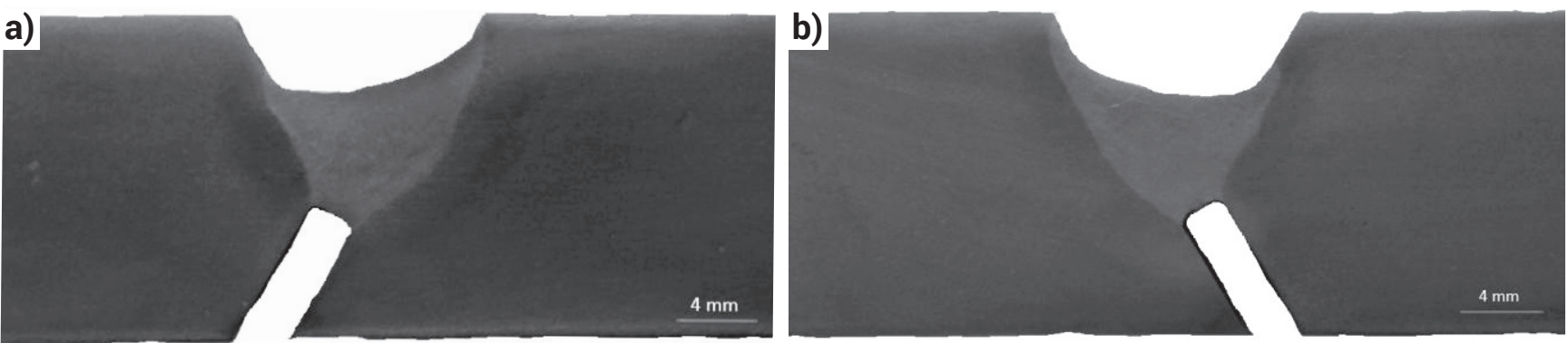

Fig. 7. Results of macroscopic testing for specimen welded in the air; a) Specimen P2.1, b) Specimen P2.2 - no imperfections 


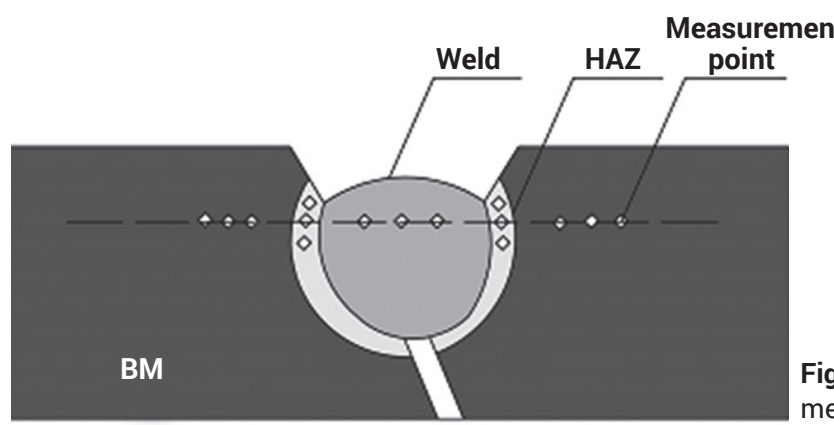

Fig. 8. Schematic layout of hardness measurement points distribution, $\mathrm{BM}$ - base material

a)

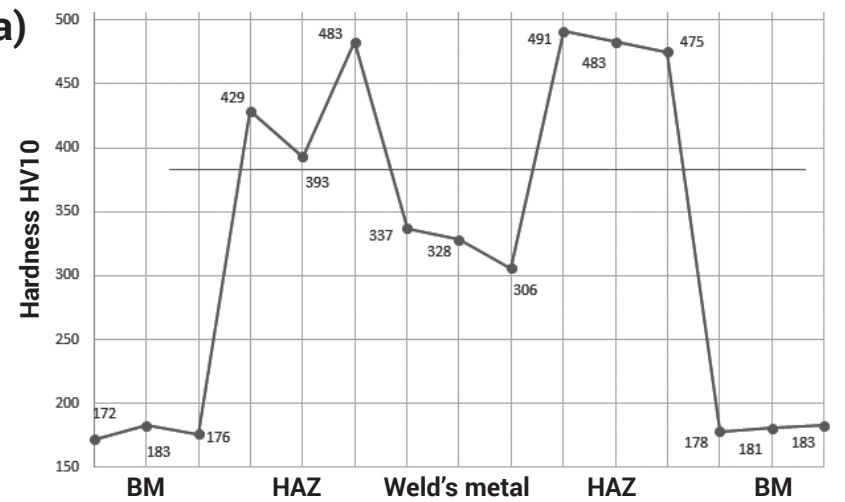

b)

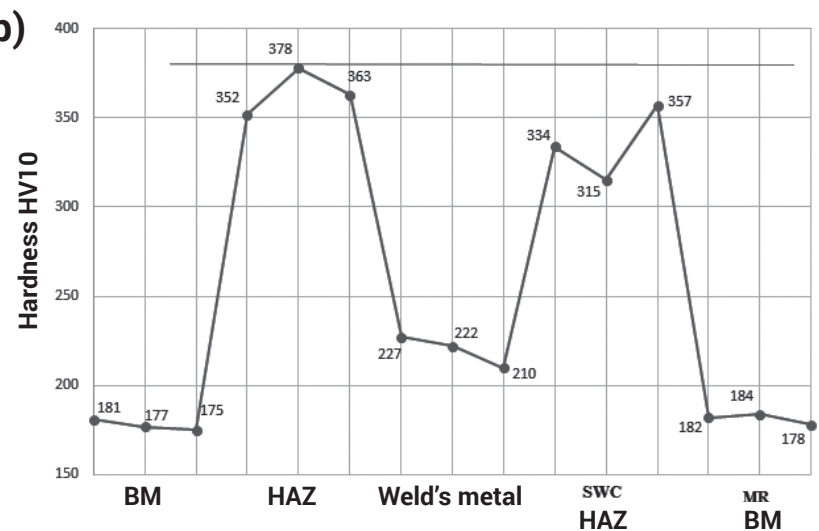

Fig. 9. Layout results of hardness tests: a) hardness distribution across W1.2 joint welded under the water, HV10max $=4 y 1$, b) haraness distribution across P1.2 joint welded in the air, HV10max $=378$

Table V. Results of Vickers HV10 hardness tests

\begin{tabular}{|c|c|c|c|c|c|c|c|c|c|c|c|c|c|c|c|}
\hline $\begin{array}{l}\text { No. } \\
\text { of the } \\
\text { sample }\end{array}$ & \multicolumn{3}{|c|}{ BM } & & HAZ & & \multicolumn{3}{|c|}{ Weld's metal } & \multicolumn{3}{|c|}{ HAZ } & \multicolumn{3}{|c|}{ MB } \\
\hline \multicolumn{16}{|c|}{ Sample welded under the water } \\
\hline W1.1 & 172 & 183 & 176 & 429 & 393 & 483 & 337 & 328 & 306 & 491 & 483 & 475 & 178 & 181 & 183 \\
\hline W1.2 & 178 & 181 & 185 & 456 & 453 & 445 & 294 & 291 & 288 & 456 & 474 & 471 & 186 & 174 & 177 \\
\hline \multicolumn{16}{|c|}{ Sample welded in the air } \\
\hline P2.1 & 175 & 184 & 174 & 338 & 341 & 305 & 230 & 215 & 215 & 336 & 307 & 340 & 184 & 187 & 179 \\
\hline P2.2 & 181 & 177 & 175 & 352 & 378 & 363 & 227 & 222 & 210 & 334 & 315 & 357 & 182 & 184 & 178 \\
\hline
\end{tabular}

\section{Summary and Conclusions}

Tekken tests carried out allowed to state that $5355 \mathrm{~J} 2 \mathrm{C}+\mathrm{N}$ steel is characterized by good weldability during welding in the air and bad in underwater conditions. It was found that the transfer of the process to water has a significant impact on the properties of joints made with coated electrodes. Already during non-destructive testing, it was found that water, as a welding environment, negatively affects the quality of joints. This conclusion was confirmed during metallographic tests. The welds made of welded joints in the air were devoid of welding imperfections, while samples made in the water environment contained cracks that separated the joint into two fragments. The Vickers HV10 hardness measurements showed negative influence of water on joint properties. It has been proven that the water environment has contributed to a significant increase in hardness in both the HAZ and the weld. For samples made under water, for each measurement point in the HAZ, it was found that the accepted hardness limit value (380 HV10) was exceeded, according to PN-EN ISO 15614$1: 2008$ value $380 \mathrm{HV} 10$, while this value was not exceeded for any samples welded in the air.

As a result of the research, the following conclusions were formulated:

1. The water welding environment significantly affected the deterioration of the quality of Tekken joints made of S355J2C+N steel made with covered electrodes. The samples contained cracks separating the joint into two parts. No imperfections were found in the case of samples from the joint welded in the open air. 
2. Welding environment significantly affects the hardness of joints. In the case of transferring the process under the water, an increase in hardness in the HAZ from 378 to $491 \mathrm{HV} 10$ max and in the weld metal from 230 to 337 HV10max was noted.

3. On the basis of the performed tests, it can be concluded that $\mathrm{S} 355 \mathrm{~J} 2 \mathrm{C}+\mathrm{N}$ steel is characterized by good weldability during welding in the air and bad in underwater conditions.

4. In order to more accurately assess the impact of the welding environment on the properties of the joints, microscopic tests are recommended.

5. In order to improve the weldability of S355J2C N steel in the water environment, welding with the use of the tempering stitch technique can be proposed.

\section{References}

[1] J. Tomków, J. Łabanowski, D. Fydrych, G. Rogalski, Cold cracking of S460N steel in water environment, Polish Maritime Research (2018), 3(99), 131-136.

[2] G. Rogalski, J. Łabanowski, D. Fydrych, J. Tomków, Bead-on-plate welding of S235JR steel by underwater local dry chambet proces, Polish Maritime Research (2014), 21, 58-64.

[3] Y. Hu, YH. Shi, XQ. Shen, ZM. Wang, Microstructore, pitting corrosion resistance and impact toughness of duplex stainless steel underwater dry hyperbaric flux-cored arc. Materials (2008), vol. 10(12), 1443.

[4] D. Purnama, W. Winarto, F. G. Susilo, Mechanical properties of underwater wet welded marine steel plates using different low hydrogen electrodes, AIP Conference Proceedings 1977, 030015, (2018), 1-5.

[5] W. B. Gao, D. Wang, F. Cheng, X. Di, W. Xu, Mictostructural and mechanical performance of underwater wet welded S355 steel, Journal of Materials Processing Technolony (2016), 238, 333-340.

[6] N. Guo, D. Liu, W. Guo, J. Feng, Effect of Ni on microstructure and mechanical properties of underwater wet welding joint, Materials\&Design (2015), 77, 25-31

[7] W. B. Gao, D. P. Wang, F. J. Cheng, C. Y. Deng, W. Xu, Underwater wet weIding for HSLA steels: chemical composition, defects, microstructures, and mechanical properties, Acta Metallurgica Sinica (English Letters) (2015), 9, 1097-1108.

[8] J. Tomków, G. Rogalski, D. Fydrych, J. Łabanowski, Improvement of S355G1+N steel weldability in water environment by Temper Bead WeIding. Journal of Materials Processing Technology (2018), 262, 372-381.

[9] H. Li, D. Liu, Y. Song, Y. Yan, N. Guo, J. Feng, Microstructure and mechanical properties of underwater wet welded high-carbon-equivalent steel Q460 using austenitic consumables, Journal of Materials Processing Technology (2017), 249, 149-157.

[10] D. Fydrych, J. Tomków, G. Rogalski, J. Łabanowski, Weldability of S460ML high strength low alloy steel in underwater conditions, Applied Mechanics and Materials (2016), 838, 10-17.
[11] A. Świerczyńska, D. Fydrych, G. Rogalski, Diffusible hydrogen management in underwater wet self-shielded flux cored arc welding, Internarional Journal of Hydrogen Energy (2017), vol. 42(38), 24532-24540.

[12] J. Wang, Q. Sun, S. Zhang, C. Wang, L. Wu, J. Feng, Characterization of underwater welding arc bubble through a visual sensing method, Journal of Materials Processing Technology (2018), 251, 95-109.

[13] D. Fydrych, G. Rogalski, J. Tomków, J. Łabanowski, Skłonność do tworzenia pęknięć zimnych złączy ze stali S420G2+M spawanej pod wodą metodą mokrą, Welding Technology Review (2013), vol. 85(10), 65-71.

[14] K. Pańcikiewicz, A. Zielińska-Lipiec, L. Tuz, Ł. Rakoczy, Ocena skłonności do pęknięć zimnych złączy spawanych stali w próbie implantacyjnej, WeIding Technology Review (2016), vol. 88(4), 63-65.

[15] T. Schaupp, M. Rhode, H. Yahyaoui, T. Kannengiesser, Influence of heat control on hydrogen distribution in high-strength multi-layer welds with narrov groove, Welding in the World (2018), 1-10.

[16] H. T. Zhang, X. Y. Dai, J. C. Feng, L. L. Hu, Preliminary investigation on real-time induction heating-assisted underwater wet welding, Welding Journal (2015), 1, 8-15.

[17] Q. Sun, W. Cheng, Y. Liu, J. Wang, C. Cai, J. Feng, Microstructure and mechanical properities of ultrasonic assisted underwater wet welding joints. Materials \& Design (2016), 103, 63-70.

[18] J. Wang, Q. Sun, L. Wu, L. Liu, J. Teng, J. Feng, Effect of ultrasonic vibration on microstructural evolution and mechanical properties of underwater wet welding joint, Journal of Materials Processing Technology (2017), 246, 185-197.

[19] J. Wang, Q. Sun, S. Zhang, C. Wang, L. Wu, J. Feng, Characterization of the underwater welding arc bubble through a visual sensing method, Journal of Materials Processing Technology (2018), 251, 96-108.

[20] J. Tomków, D. Fydrych, G. Rogalski, J. Łabanowski, Temper bead welding od S460N steel in wet welding coiditions, Advances in Materials Science (2018), vol. 18(3), 5-14.

[21] Katalog producenta elektrod Omnia, firmy Lincoln Electic.

(C) 2019 by the authors. Submitted for possible open access publication under the terms and conditions of the Creative Commons Attribution (CC BY) license (http://creativecommons.org/licenses/by/4.0/). 